\title{
Lotte Nyboe: Digital dannelse. Børn og unges mediebrug og -laering inden for og uden for institutionerne. København: Frydenlund. 2009.
}

\author{
Stine Liv Johansen
}

MedieKultur 2010, 49, 179-181

\section{Published by SMID | Society of Media researchers In Denmark | www.smid.dk} The online version of this text can be found open access at www.mediekultur.dk

Hvordan er sammenhængen mellem den læring, der er på skemaet i skoler, daginstitutioner og fritidstilbud, og den læring, børn og unge får 'med i købet' i deres medialiserede fritidsliv og legekultur? Det spørgsmål sætter Lotte Nyboe sig for at undersøge i bogen Digital Dannelse. Bogen henvender sig i første omgang til lærere, pædagoger og børnekulturkonsulenter, der i deres daglige arbejde omgås nutidens omflakkende, multimediale og (måske?) mediekompetente børn og unge. Med afsæt i denne målgruppe gives en bred karakteristik af, hvad der kendetegner børn og unges liv i "den digitale, globaliserede mediekultur". Der zoomes fra samfundsperspektiv, senmodernitet, postindustrialisme og skolens og fritidens mediebrug ind på konkrete cases, hvor børn bruger mobiltelefon og internet eller deltager i animationsværksted. Dette brede perspektiv er på samme tid bogen styrke og svaghed. Styrke, fordi det giver en god introduktion til problemfeltet til folk, der ikke har for eksempel medievidenskab og kulturanalyse som deres daglige genstandsfelt, men svaghed, fordi den i sin iver efter at dække så bredt savner noget dybde, der kunne bidrage til den forskningsmæssige diskussion inden for feltet.

Bogen falder i en indledning samt fem kapitler. I indledningen slås den grundlæggende problematik an: at der er himmelråbende stor forskel på den brug af medier, børn og unge har i deres fritidsliv, og så den brug af medier, de præsenteres for i (især) skolen. Hvor fritidens mediekultur generelt er præget af mangfoldighed, er skolens ditto generelt fokuseret på en lidt gammeldags, smalsporet brug af for eksempel kontorprogrammer og informationssøgning. Og dette er problematisk, skriver Nyboe, fordi børn og unge dermed selv er 
ansvarlige for at tilegne sig de kompetencer, der er nødvendige $i$ et mediesamfund. Det bunder i, at der er forskel på, hvordan generationerne opfatter og bruger medier. Hvor de ældre generationer - herunder beslutningstagere og mange lærere i skolen - opfatter forskellige medier som adskilte og tilknyttet forskellige brugsmønstre, så opfatter og bruger børn og unge medier som et sammenhængende hele. Der er altså tale om et fragmenteret versus et konvergent mediebillede, der gør, at børn/unge og voksne/ældre ikke umiddelbart forstår hinanden.

I de følgende kapitler præsenterer bogen et overblik over de aktuelle diskurser og diskussioner, når det handler om samfund, kultur, læring, media literacy og mediekulturen i og uden for institutionerne. Den veksler mellem store og små teorier om, hvordan eksempelvis samfundet ser ud efter år 2000, og konkrete eksempler på, hvordan dette kommer til udtryk i hverdagslivet. Denne bog lider i den sammenhæng af et handicap, som det er uden for dens rækkevidde at gøre noget ved, nemlig at de valgte, analyserede eksempler i løbet af den produktionstid, en bog som denne nødvendigvis må have, bliver uaktuelle. Det gælder titler på tv-programmer eller -kanaler eller på netsteder, der for et par år siden var 'talk of the town', men som nu synes glemt. I hvert fald blandt børn og unge. Som sagt er det et vilkår, ikke blot for denne bog, men for alle os, der beskæftiger os med nutidskultur, men det er alligevel problematisk, når målgruppen tages i betragtning. Skulle en læser - for eksempel en skolelærer - have den forestilling, at han efter at have læst Nyboes bog er nede med sine elevers fritids- og mediekultur, må han desværre tro om igen. Det er ikke aktualiteten, der er denne bogs fornemste bidrag.

Det er derimod dens bredde og dens fortløbende argument, der fra samfundsniveauet tager læseren med på en fin gennemgang af forskellige ideer om læring - formel, uformel og sammenhængen mellem leg og læring. Disse knyttes til begreber om kompetence og dannelse, og et bud på et moderne dannelsesbegreb, digital dannelse, der er knyttet til bred kulturel kompetence, præsenteres. Herefter præsenteres et tilsvarende moderne begreb om media literacy, der særligt er funderet på Buckinghams udlægning af dette. Igen er der tale om et sæt af kompetencer, der ikke blot gør børn og unge i stand til at afkode og gennemskue mediernes budskaber, men kompetencer, der gør børn og unge i stand til at bruge medier aktivt i sociale fællesskaber. Præcis som man vil se, at mange gør det i fritidens mediekultur.

Netop denne mediekultur er i fokus i bogens tredje kapitel, der tager pulsen (med ovenstående forbehold for aktualitet) på børn og unges mediebrug i fritiden. En bred og mangfoldig brug, der blandt andet handler om "leg, kommunikation, oplysning og underholdning", og som kombinerer nye og gamle medier. Kapitlet slår endnu engang fast, at nye medier ikke fortrænger de gamle, men at de blandt børn og unge blot anvendes i kombination og parallelt. Via mobiltelefonen og internettet som cases præsenteres både positive og negative aspekter af børn og unges brug. Der fokuseres således både på de færdigheder, børn og unge kan opnå ved at bruge tiden for eksempel på nettet, og på de risici, deres færden her også indebærer. Både færdigheder og risici er knyttet til dels et mediespecifikt 
kompetenceniveau og dels et generelt dannelsesmæssigt niveau og bør tages alvorligt af skolen, så den både udnytter børn og unges potentialer og ruster dem til at tackle de udfordringer, de måtte støde på.

I bogens fjerde kapitel tages fat på de dilemmaer, der præger brugen af medier i skole og institutioner. Det er her, voksne, der ikke selv er vokset op med et særlig mangfoldigt medieudbud, møder de tidligere beskrevne børn og unge, og det er ikke mindst her, at en politisk dagsorden, der eksempelvis udmønter sig i læreplaner, udspiller sig. Dette kommer til udtryk i en række skismaer, eksempelvis mellem ung og gammel, mellem fritidskultur ( $i$ daginstitutioner og SFO'er) og læreplaner og ikke mindst mellem ovenfra kommende politiske krav og den måde, disse kan effektueres i institutionerne, der blandt andet kæmper med dårlig økonomi og lærere, der ikke kan eller vil tage nye medier og teknologier til sig $\mathrm{i}$ undervisningen. Der tegnes derfor et billede af en institutionssektor, der ikke helt er klædt på til at møde samfundets og ikke mindst børnenes og de unges forventninger i forhold til at leve op til et moderne begreb om digital dannelse.

Afslutningsvis præsenteres i bogens femte kapitel endnu en case, nemlig animationsværkstedet i Viborg, der beskrives som et eksempel på, hvordan medieæstetisk læring kan finde sted, så det imødekommer en lang række af ovenstående forventninger. Dette sidste kapitel fungerer mest af alt som en blød landing i forhold til de i bogen skitserede problematikker. Lidt for blød, måske, for det ville have været frigørende, om bogen havde turdet tage skridtet fuldt ud, så den kunne have været en endnu mere vigtig og vægtig stemme i debatten om for eksempel folkeskolens fremtid eller om forskningens bidrag til mediepædagogikken. Som den er nu, er bogen en rigtig god introduktion til feltet, der vil være væsentlig at orientere sig i for især pædagoger og lærere, og et godt bud på en grundig fundering af nødvendige debatter fremover.

Stine Liv Johansen

Adjunkt, ph.d.

Center for Playware, Institut for Didaktik, DPU

Aarhus Universitet

slj@dpu.dk 